Commentaries on judicial decisions $\frac{\text { Studia luridica Lublinensia vol. XXX, 4, } 2021}{\text { DOI: 10.17951/sil.2021.30.4.655-674 }}$

\author{
Dawid Marko \\ University of Gdańsk, Poland \\ ORCID: 0000-0001-9578-7405 \\ dawid.marko@prawo.ug.edu.pl
}

\title{
Dopuszczalność orzeczenia przez sąd odwoławczy wyrokiem łącznym kary łącznej po raz pierwszy albo orzeczenia jej w zakresie innym niż orzekł sąd pierwszej instancji. Glosa do uchwały składu 7 sędziów Sądu Najwyższego z dnia 28 czerwca 2018 r. (I KZP 3/18, OSNKW 2018, nr 8, poz. 55)
}

\begin{abstract}
Admissibility of the Issuing Cumulative Penalty in Cumulative Judgement by Appeal Court for the First Time or Issuing That Penalty Within the Different Scope of Punishment: Commentary on the Resolution of the Panel of 7 Judges of the Supreme Court of 28 June 2018 (I KZP 3/18, OSNKW 2018, no. 8, item 55)
\end{abstract}

\section{ABSTRAKT}

W glosie poruszono problem dopuszczalności orzeczenia przez sąd odwoławczy po raz pierwszy kary łącznej lub wymierzenia jej w zakresie innym niż sąd pierwszej instancji z punktu widzenia zasady dwuinstancyjności, dostępu do sądu i prawa do obrony. Dokonując analizy rozwiązań konstytucyjnych i konwencyjnych, autor podejmuje próbę udzielenia odpowiedzi na pytanie, jaki jest zakres uprawnienia sądu odwoławczego do zmiany wyroku łącznego sądu pierwszej instancji. Rozważania prowadzą do wniosku, że ani art. 176 ust. 1 Konstytucji RP, ani art. 6 Europejskiej Konwencji Praw Człowieka (EKPC) i uzupełniający jego treść art. 2 Protokołu nr 7 do EKPC, jak również art. 14 ust. 5 Międzynarodowego Paktu Praw Obywatelskich i Politycznych zasadniczo nie stoją ku temu na przeszkodzie, co powinno znaleźć odzwierciedlenie w procesie wykładni art. 437 § 2 Kodeksu postępowania karnego. Zdaniem autora wątpliwości, z omawianej perspektywy, budzi jednak sytu-

CORRESPONDENCE ADDRESS: Dawid Marko, MA, Research Assistant, University of Gdańsk, Faculty of Law and Administration, Bażyńskiego 6, 80-309 Gdańsk, Poland. 
acja, w której sąd odwoławczy miałby uwzględnić przy wymierzaniu kary łącznej karę jednostkową nieznaną, z różnych względów, sądowi pierwszej instancji, czemu szczególnie poświęcono część rozważań i uwag krytycznych.

Słowa kluczowe: postępowanie karne; sąd odwoławczy; zasada dwuinstancyjności; dostęp do sądu; prawo do obrony; wyrok łączny

\section{TEZY UCHWAEY}

1. W sprawie o wydanie wyroku łącznego sąd odwoławczy może orzec po raz pierwszy karę łączną, gdy w pierwszej instancji został wydany zaskarżony apelacją wyrok łączny, orzekający karę na bazie określonych skazań oraz umarzający postępowanie na podstawie art. 572 k.p.k. ${ }^{1} \mathrm{~W}$ pozostałym zakresie.

2. Nie jest także wykluczone orzeczenie przez sąd odwoławczy kary łącznej w oparciu o skazania, które nie były podstawą orzeczenia kary łącznej przez sąd pierwszej instancji.

Kluczowe zagadnienie, z jakim przyszło zmierzyć się Sądowi Najwyższemu w komentowanej uchwale, odnosi się do normatywnych ograniczeń możliwości wydania reformatoryjnego rozstrzygnięcia przez sąd odwoławczy, rozpatrywanych z punktu widzenia zasad dwuinstancyjności, prawa do obrony oraz prawa do zaskarżenia orzeczenia wydanego w pierwszej instancji. W istocie chodzi zatem o szeroko dyskutowaną w orzecznictwie i w literaturze kwestię związaną z nadaniem odpowiedniego znaczenia postulatom zasady dwuinstancyjności w aspekcie kompetencji sądu do wydania orzeczenia reformatoryjnego w postępowaniu odwoławczym. Wydawać by się mogło, że podjęta w uchwale kwestia, w toku wieloletniej eksploracji, otrzymała wyczerpujące opracowanie, które wyklucza powstanie w praktyce jakichkolwiek kontrowersji. Fakt podjęcia przez Sąd Najwyższy komentowanej uchwały dowodzi jednak, że praktyka wciąż dostarcza nowych wyzwań. Omówiony w uchwale problem ma przy tym o tyle niecodzienny charakter, że objawił się nie - jak ma to zwykle miejsce - w postępowaniu zwyczajnym, lecz w postępowaniu w sprawie o wydanie wyroku łącznego, co pozwala unaocznić uniwersalny charakter i ważką rolę komentowanej materii w procesie karnym.

${ }^{1}$ Ustawa z dnia 6 czerwca 1997 r. - Kodeks postępowania karnego (t.j. Dz.U. 2020, poz. 30 ze zm.). 
Przechodząc do oceny głównej tezy glosowanego orzeczenia, należy wyrazić przekonanie, że zasługuje ona na aprobatę i wpasowuje się w utrwalony już nurt wypowiedzi judykatury, zgodnie z którym wzorzec zasady dwuinstancyjności należy rozumieć formalnie. $\mathrm{W}$ istocie zagadnienie dopuszczalności orzekania reformatoryjnego przez sąd odwoławczy nierozerwalnie powiązane jest z prawem do sądu drugiej instancji, zaliczanym do standardów rzetelnego procesu. Procesowa zasada dwuinstancyjności znajduje swoje odwzorowanie w konstytucyjnej zasadzie co najmniej dwuinstancyjnego postępowania, wyrażonej w art. 176 ust. 1 Konstytucji RP. ${ }^{2} \mathrm{~W}$ piśmiennictwie wskazuje się, że Konstytucja $\mathrm{RP}^{3}$ nie rozstrzyga przy tym, jaki powinien być właściwy model postępowania dwuinstancyjnego ani W szczególności nie określa sposobu funkcjonowania środków odwoławczych. ${ }^{4}$ Ustawa zasadnicza, jakkolwiek określa zakres gwarancji przysługujących uczestnikom postępowania, nie zawsze przesądza o sposobie ich zapewnienia. ${ }^{5}$ Zgodnie z orzecznictwem Trybunału Konstytucyjnego zasada dwuinstancyjności poręcza kontrolę rozstrzygnięcia podejmowanego przez sąd pierwszej instancji poprzez gwarancję dwukrotnej oceny stanu faktycznego i prawnego sprawy oraz kontroli stanowiska zajętego przez sąd pierwszej instancji, ${ }^{6}$ a także służy zapobieganiu pomyłkom i arbitralności decyzji podejmowanych przez sąd pierwszej instancji. ${ }^{7}$ Tak jak w art. 45 ust. 1 Konstytucji RP zagwarantowane jest „rozpoznanie sprawy”, tak na gruncie zasady dwuinstancyjności dotyczy ono procesu decyzyjnego, a więc pierwszego rozstrzygnięcia w sprawie. ${ }^{8}$ Analizując zakres gwarancji określonych art. 176 ust. 1 Konstytucji RP, Trybunał Konstytucyjny stwierdził, że regulacja ta nie sprzeciwia się reformatoryjnemu orzekaniu sądu odwoławczego, ${ }^{9}$ gdyż po rozpatrzeniu sprawy sąd drugiej instancji może dokonać odmiennej oceny dowodów i w konsekwencji rozbieżnego ustalenia stanu faktycznego i prawnego niż sąd pierwszej instancji oraz może wydać wyrok niekorzystny dla strony. Nie oznacza to jednak, że wyrok ten staje się orzeczeniem pierwszoinstancyjnym, od którego

${ }^{2}$ Uchwała SN w składzie 7 sędziów z dnia 28 czerwca 2018 r., I KZP 3/18, OSNKW 2018, nr 8, poz. 55 .

${ }^{3}$ Konstytucja Rzeczypospolitej Polskiej z dnia 2 kwietnia 1997 r. (Dz.U. 1997, nr 78, poz. 483 ze zm.).

${ }^{4}$ P. Wiliński, Konstytucyjne uwarunkowania postępowania odwoławczego w procesie karnym, [w:] Postepowanie odwolawcze w procesie karnym - u progu nowych wyzwań, red. S. Steinborn, Warszawa 2016, s. 105-106.

5 Idem, Konstytucyjne gwarancje prawa karnego procesowego, [w:] System Prawa Karnego Procesowego, t. 1, cz. 1: Zagadnienia ogólne, red. P. Hofmański, Warszawa 2013, s. 673-831.

${ }^{6}$ Wyrok TK z dnia 13 lipca 2009 r., SK 46/08, OTK-A 2009, nr 7, poz. 109.

7 Wyrok TK z dnia 12 czerwca 2002 r., P 13/01, OTK-A 2002, nr 4, poz. 42.

${ }^{8}$ Wyrok TK z dnia 13 lipca 2009 r., SK 46/08, OTK-A 2009, nr 7, poz. 109.

${ }^{9}$ Wyrok TK z dnia 11 marca 2003 r., SK 8/02, OTK-A 2003, nr 3, poz. 20. 
musiałby przysługiwać kolejny środek odwoławczy. ${ }^{10} \mathrm{~W}$ orzecznictwie Trybunału Konstytucyjnego zaznacza się również, że o kwalifikacji postępowania jako toczącego się przed pierwszą lub drugą instancją nie może rozstrzygać jedynie fakt, że dana kwestia została rozpoznana po raz pierwszy. ${ }^{11}$

Analiza zakresu zasady dwuinstancyjności stanowiła również przedmiot zainteresowania Izby Karnej Sądu Najwyższego, która w swym najnowszym orzecznictwie skłania się ku wnioskowi, że gwarancja dwuinstancyjnego postępowania, wynikająca $\mathrm{z}$ art. 176 ust. 1 Konstytucji RP, musi być interpretowana formalnie, a nie materialnie, ${ }^{12}$ natomiast sąd odwoławczy jest przede wszystkim sądem merytorycznym. ${ }^{13}$ Obecnie takie rozumienie omawianej zasady aprobowane jest również w doktrynie. ${ }^{14}$ Oznacza to, że w odniesieniu do każdego rozstrzygnięcia zawartego w orzeczeniu sądu odwoławczego, które zawiera w sobie pewien element nowości $\mathrm{w}$ zestawieniu z orzeczeniem poddawanym takiej kontroli, nie musi być otwarta

${ }^{10}$ Postanowienie TK z dnia 14 maja 2013 r., Ts 216/12, OTK-B 2013, nr 5, poz. 498; postanowienie TK z dnia 24 maja 2017 r., Ts 205/16, OTK-B 2017, poz. 149.

11 Wyrok TK z dnia 12 stycznia 2010 r., SK 2/09, OTK-A 2010, nr 1, poz. 1.

12 Uchwała SN w składzie 7 sędziów z dnia 23 marca 2011 r., I KZP 28/10, OSNKW 2011, nr 4, poz. 30; postanowienie SN z dnia 27 stycznia 2015 r., IV KK 195/14, OSP 2016, nr 2, poz. 18; postanowienie SN z dnia 8 grudnia 2010 r., II KK 288/10, BPK 2011, nr 1, poz. 1. W przeszłości można było spotkać się także z odmiennym rozumieniem istoty dwuinstancyjności. Zob. wyrok SN z dnia 26 marca 2008 r., V KK 389/07, OSNKW 2008, nr 8, poz. 61; wyrok SN z dnia 18 listopada 2008 r., II KK 121/08, BPK 2009, nr 1, poz. 10.

13 Postanowienie SN z dnia 24 października 2017 r., V KK 265/17, LEX nr 2408341.

${ }_{14}$ P. Hofmański, Nowy model postępowania odwoławczego w postępowaniu karnym, [w:] Postępowanie odwoławcze ..., s. 99-100; S. Steinborn, Postepowanie dowodowe w instancji apelacyjnej w świetle nowelizacji kodeksu postępowania karnego, „Prokuratura i Prawo” 2015, nr 1-2, s. 161; M. Fingas, Orzekanie reformatoryjne w instancji odwoławczej w polskim procesie karnym, Warszawa 2016, s. 100; D. Świecki, Konstytucyjna zasada dwuinstancyjności postępowania sądowego a możliwość reformatoryjnego orzekania $w$ instancji odwoławczej w świetle wchodzacej w życie 1 lipca 2015 r. nowelizacji kodeksu postępowania karnego, [w:] Polski proces karny i materialne prawo karne w świetle nowelizacji z 2013 roku. Ksiegga jubileuszowa dedykowana Profesorowi Januszowi Tylmanowi z okazji Jego 90. urodzin, red. T. Grzegorczyk, Warszawa 2014, s. 222-223; P. Wiliński, Dwuinstancyjność postępowania karnego w świetle Konstytucji, [w:] Funkcje procesu karnego. Księga jubileuszowa Profesora Janusza Tylmana, red. T. Grzegorczyk, Warszawa 2011, s. 565-580; P. Hofmański, S. Zabłocki, Dowodzenie w postepowaniu apelacyjnym i kasacyjnym - kwestie modelowe, [w:] Funkcje procesu karnego..., s. 474-476; W. Hermeliński, B. Nita, Orzekanie reformatoryjne w procesie karnym na podstawie nowych ustaleń faktycznych, „Państwo i Prawo” 2009, z. 4, s. 68-69; S. Steinborn, Ograniczenie zaskarżalności wyroku wydanego $w$ I instancji jako środek uproszczenia procesu karnego w świetle prawa do dwuinstancyjnego postępowania (uwagi de lege lata i de lege ferenda), „Gdańskie Studia Prawnicze” 2005, $\mathrm{nr}$ 1, s. 365-389; M. Błoński, Zasada dwuinstancyjności a reformatoryjny wyrok sądu odwoławczego, [w:] Istota i zasady procesu karnego 25 lat później. Księga poświęcona pamięci Profesora Andrzeja Murzynowskiego, red. H. Gajewska-Kraczkowska, M. Rogacka-Rzewnicka, Warszawa 2019, s. 31-40; M. Klejnowska, Ograniczenia sądu odwoławczego orzekającego w sprawie karnej po wniesieniu środka zaskarżenia, Rzeszów 2008, passim; A. Kaftal, System środków odwoławczych w polskim procesie karnym (rozważania modelowe), Warszawa 1972, passim. 
droga kontroli instancyjnej. Odmienne rozumienie gwarancji dwuinstancyjności oznaczałoby bowiem, że najmniejsza korekta orzeczenia sądu pierwszej instancji, dokonana przez sąd odwoławczy, byłaby wykluczona, skoro orzeczenie sądu odwoławczego nie podlega kontroli odwoławczej. ${ }^{15}$ Słowem, konstytucyjna zasada dwuinstancyjności nie zawiera w sobie nakazu przyjęcia kasatoryjnych rozwiązań w postępowaniu odwoławczym, które miałyby wykluczyć możliwość reformatoryjnego orzeczenia przez sąd ad quem, zapewniając oskarżonemu badanie każdego „materialnie pierwszego” a negatywnego dlań rozstrzygnięcia, lub nawet jego elementu, przed dwiema instancjami. Dlatego też należy odróżnić konstytucyjną gwarancję dwuinstancyjności od określonych ustawowo granic kompetencji orzekania sądu odwoławczego. Rozstrzygając co do meritum sprawy odmiennie niż sąd a quo, sąd ad quem działa w granicach przyznanej mu ustawą kognicji, która - z zastrzeżeniem ograniczeń narzuconych treścią art. 433 § 1 k.p.k. - odpowiada zasadniczo tej, jaką dysponował sąd a quo. Mimo zatem, że od orzeczenia sądu ad quem nie przysługuje już zwykły środek zaskarżenia, nie zmienia to faktu, że jest to rozstrzygnięcie drugoinstancyjne, wydane zgodnie z kompetencjami ustawowymi. ${ }^{16}$

Trudno również doszukiwać się podstaw dla odmiennego poglądu niż podzielony przez Sąd Najwyższy w omawianym judykacie na gruncie art. 14 ust. 5 MPPOiP. ${ }^{17}$ Przepis ten nie zawiera treści normatywnej nakazującej zapewnienie oskarżonemu dwukrotnej kontroli każdego potencjalnie negatywnego rozstrzygnięcia. Gwarantuje on, że każda osoba skazana za przestępstwo ma prawo odwołania się do sądu wyższej instancji w celu ponownego rozpatrzenia orzeczenia o winie i karze zgodnie z ustawą. Prawidłowa interpretacja normy wywodzonej z omawianego przepisu wymaga zapewnienia oskarżonemu odwołania do sądu wyższej instancji w przypadku, gdy do skazania doszło po raz pierwszy przed sądem odwoławczym ${ }^{18}$ jednakże w przypadku wydawania wyroku łącznego do skazania przecież nie dochodzi. Specyfika postępowania o wydanie wyroku łącznego nie wiąże się z przełamywaniem zasady domniemania niewinności - sąd w tym postępowaniu nie bada podstaw odpowiedzialności karnej oskarżonego, gdyż dysponuje już wyrokami odpowiedzialność tę przypisującymi, będąc związanym ich treścią, a jego

${ }^{15}$ Uchwała SN w składzie 7 sędziów z dnia 23 marca 2011 r., I KZP 28/10, OSNKW 2011, nr 4, poz. 30 .

16 D. Świecki, op. cit., s. 222-223.

17 Międzynarodowy Pakt Praw Obywatelskich i Politycznych z dnia 19 grudnia 1966 r. (Dz.U. 1977, nr 38, poz. 167).

${ }_{18} \mathrm{M}$. Wąsek-Wiaderek, Wybrane aspekty postępowania odwoławczego w procesie karnym po 1 lipca 2015 r. w świetle standardów międzynarodowych, [w:] Postępowanie odwoławcze..., s. 157; W. Jasiński, Redukcja postępowania przed sądem pierwszej instancji a konstytucyjny i konwencyjny standard prawa do odwolania sie w sprawach karnych, [w:] Postępowanie odwoławcze..., s. 120; A. Gliszczyńska-Grabias, K. Sękowska-Kozłowska, R. Wieruszewski, [w:] Międzynarodowy Pakt Praw Obywatelskich (osobistych) i Politycznych. Komentarz, red. R. Wieruszewski Warszawa 2012, s. 331. 
rzeczą jest ukształtowanie na nowo kary z wyroków podlegających łączeniu. Pewne potwierdzenie zaprezentowanego rozumowania można odnaleźć w literalnym odczytaniu art. 568a § 1 k.p.k., który rozróżnia przecież wyrok skazujący i wyrok łączny. Stanowisko takie występuje również w doktrynie. ${ }^{19}$ Wyroku skazującego nie sposób więc utożsamiać z wyrokiem łącznym, co czyni się nieraz w orzecznictwie. ${ }^{20}$ Należy również nadmienić, że na gruncie art. 14 ust. 5 MPPOiP prawo do środka odwoławczego ma obejmować ponowną ocenę nie tylko kwestii formalnych, lecz także całego stanu faktycznego sprawy. ${ }^{21}$ Dokonując zaś oceny zarzutów skierowanych wobec rozstrzygnięcia sądu pierwszej instancji, sąd odwoławczy może dopuścić nowe dowody i orzec reformatoryjnie. ${ }^{22}$

Takiemu rozumieniu zasady dwuinstancyjności nie sprzeciwia się również Europejska Konwencja o Ochronie Praw Człowieka. ${ }^{23}$ Zgodnie z ugruntowanym poglądem art. 6 EKPC, określający prawo do rzetelnego procesu sądowego, nie gwarantuje ani dostępu do instancji odwoławczej, ani prawa do apelacji. ${ }^{24}$ Prawo do odwołania się od wyroku sądu pierwszej instancji zostało zagwarantowane dopiero $\mathrm{w}$ art. 2 Protokołu nr 7 do EKPC, ${ }^{25}$ niemniej dotyczy ono tylko spraw karnych, a dokładnie wyroku przypisującego winę. Protokół ten pozostawia ustawodawcy krajowemu swobodę w zakresie kształtowania postępowania odwoławczego, wprost zastrzegając, że korzystanie z tego prawa oraz jego podstawy reguluje ustawa. Europejska Konwencja o Ochronie Praw Człowieka w zasadzie nie narzuca modelu postępowania odwoławczego, wykluczając jedynie taki jego kształt, który stanowiłby zaprzeczenie idei kontroli instancyjnej. ${ }^{26}$ Dopuszczalne jest ograniczenie

19 J. Grajewski, S. Steinborn, [w:] Kodeks postepowania karnego. Komentarz, red. L.K. Paprzycki, t. 2, Warszawa 2013, s. 152-153.

${ }^{20}$ Por. wyrok SA w Katowicach z dnia 10 stycznia 2008 r., II AKa 546/07, KZS 2008, nr 4, poz. 109; wyrok SA w Katowicach z dnia 4 kwietnia 2013 r., II AKa 53/13, LEX nr 1311956.

${ }^{21}$ Decyzja Komitetu Praw Człowieka z dnia 28 marca 2006 r., Bandajewski v. Białoruś, skarga nr 1100/2002, pkt 10.13 .

${ }^{22}$ Komentarz ogólny nr 32 do art. 14 MPPOiP, pkt 48, U.N. Doc. CCPR/GC/32 (2007), cz. VII; decyzja Komitetu Praw Człowieka z dnia 24 lipca 2006 r., Larranaga v. Filipiny, pkt 7.8.

${ }^{23}$ Konwencja o Ochronie Praw Człowieka i Podstawowych Wolności z dnia 4 listopada 1950 r. (Dz.U. 1993, nr 61, poz. 284 ze zm.), dalej: EKPC.

${ }^{24}$ M.A. Nowicki, Wokót Konwencji Europejskiej. Komentarz do Europejskiej Konwencji Praw Człowieka, Warszawa 2017, s. 552; P. Hofmański, A. Wróbel, Komentarz do Konwencji o ochronie praw człowieka i podstawowych wolności, t. 1, Warszawa 2010, s. 289-290; S. Steinborn, Ograniczenie zaskarżalności wyroku..., s. 369. Por. wyrok ETPC z dnia 17 stycznia 1970 r., Delcourt v. Belgia, skarga nr 2689/65, § 25 in fine; wyrok ETPC z dnia 26 października 2000 r., Kudła v. Polska, skarga nr 30210/96, § 122; wyrok ETPC z dnia 30 stycznia 2018 r., Brajović v. Czarnogóra, skarga nr 52529/12, § 49 in fine; wyrok ETPC z dnia 22 lutego 2011 r., Lalmahomed v. Holandia, skarga nr 26036/08, § 34-38 (powołane tu i dalej orzeczenia ETPC są dostępne w bazie HUDOC).

${ }^{25}$ Protokół nr 7 do Konwencji o Ochronie Praw Człowieka i Podstawowych Wolności z dnia 22 listopada 1984 r. (Dz.U. 2003, nr 42, poz. 364).

${ }^{26}$ Wyrok ETPC z dnia 25 lipca 2017 r., Rostovtsev v. Ukraina, skarga nr 2728/16, § 27-28. 
kognicji sądu odwoławczego poprzez poddanie jego kontroli jedynie kwestii prawnych (points of law), z wyłączeniem sfery ustaleń faktycznych. ${ }^{27} \mathrm{~W}$ standardach Europejskiej Konwencji o Ochronie Praw Człowieka mieści się więc wyposażenie sądu odwoławczego w instrumentarium umożliwiające orzekanie reformatoryjne, w tym skrajnie niekorzystna zmiana orzeczenia sądu pierwszej instancji, bez prawa do dalszego kwestionowania takiej zmiany. ${ }^{28}$ Należy podkreślić, że tak jak w przypadku Międzynarodowego Paktu Praw Obywatelskich i Politycznych, tak i w europejskim systemie ochrony praw człowieka prawo do kontroli wyroku sądu pierwszej instancji odnosi się jedynie do przypadku przełamania domniemania niewinności (convinction, déclaré coupable), a więc nie obejmuje sprawy o wydanie wyroku łącznego.

Również z orzecznictwa Trybunału Sprawiedliwości Unii Europejskiej zdaje się nie wynikać, aby w związku z treścią art. 47 ust. 2 Karty Praw Podstawowych Unii Europejskiej ${ }^{29}$ na państwach członkowskich ciążył obowiązek utworzenia instancji odwoławczych. W piśmiennictwie stwierdza się, że wskazany przepis, utożsamiany z art. 6 i 13 EKPC, przewiduje prawo do zbadania sprawy jedynie w jednej instancji sądowej. ${ }^{30}$

Nie ma również powodów, aby poszukiwać dodatkowych ograniczeń orzekania reformatoryjnego w zasadzie prawa do obrony, co trafnie dostrzegł Sąd Najwyższy w glosowanej uchwale. Argument przeciwny ma ograniczoną siłę przekonywania, gdyż istota konstytucyjnego prawa do obrony (art. 42 ust. 2 Konstytucji RP) nie gwarantuje ani prawa do zaskarżenia orzeczenia, ani nieorzekania na niekorzyść oskarżonego w postępowaniu odwoławczym. ${ }^{31} \mathrm{~W}$ wyroku z dnia 28 kwietnia $2009 \mathrm{r}$. Trybunał Konstytucyjny skonstatował, że zakaz orzekania na niekorzyść oskarżonego przez sąd odwoławczy nie stanowi esencjonalnego elementu prawa do obrony, bez którego prawo to w postępowaniu przed sądem ad quem nie byłoby zagwarantowane. Zakaz ten stanowi jedynie element dodatkowy (otoczkę) prawa do obrony, pełniąc wobec niego rolę służebną. ${ }^{32}$ Zmiana orzeczenia w instancji od-

27 Wyrok ETPC z dnia 30 października 2014 r., Shyvdka v. Ukraina, skarga nr 17888/12, § 49; wyrok ETPC z dnia 4 czerwca 2015 r., Ruslan Yakovenko v. Ukraina, skarga nr 5425/11, § 77-78; wyrok ETPC z dnia 9 listopada 2017 r., Firat v. Grecja, skarga nr 46005/11, § 37.

${ }_{28}^{28}$ M. Fingas, op. cit., s. 88.

29 Dz.Urz. UE C 303, 14.12.2007, s. 391-407.

${ }^{30}$ H.J. Blanke, [w:] EUV/AEUV. Das Verfassungsrecht der Europäischen Union mit Europäischer Grundrechtecharta Kommentar, hrsg. v. Ch. Caliess, M. Ruffert, München 2011, s. 2945-2948, za: P. Grzegorczyk, K. Weitz, [w:] Konstytucja RP. Komentarz, red. L. Bosek, M. Safjan, t. 1, Warszawa 2016, s. 1785. Por. wyrok TSUE z dnia 17 lipca 2014 r. w sprawie C-169/16, Sánchez Morcillo i Abril Garcia, ECLI:EU:C:2014:2099.

${ }_{31}$ M. Fingas, op. cit., s. 121; wyrok TK z dnia 17 maja 2004 r., SK 32/03, OTK-A 2004, nr 5, poz. 44 (TK wskazał tu, że sam art. 42 ust. 2 Konstytucji RP nie zapewnia prawa do zaskarżenia orzeczenia, gdyż pozostaje to w materii art. 176 ust. 1 Konstytucji RP).

${ }^{32}$ Wyrok TK z dnia 28 kwietnia 2009 r., P 22/07, OTK-A 2009, nr 4, poz. 55. 
woławczej per se nie powoduje zatem pozbawienia oskarżonego prawa do obrony. Dotychczasowe rozważania dały podstawę również do sformułowania wniosku, że żadna norma rangi konstytucyjnej czy konwencyjnej nie pozwala na wyprowadzenie zakazu reformatoryjnego orzekania przez sąd odwoławczy na niekorzyść oskarżonego (poza sytuacją tzw. odwrócenia orzeczenia, określoną w art. $454 \S 1$ k.p.k.). Nie sposób się też zgodzić, aby postępowanie odwoławcze - w jego obecnym modelu - ograniczało możliwość obrony. Postępowanie odwoławcze stanowi pewne continuum postępowania przed sądem pierwszej instancji, gdzie oskarżony może bronić się tak samo jak w postępowaniu pierwszoinstancyjnym. Różnica sprowadza się jedynie do sposobu wyeliminowania uchybień sądu pierwszej instancji. ${ }^{33}$

\section{3.}

W następstwie powyższych uwag należy stwierdzić, że prawo do sądu wyrażone w art. 45 ust. 1 Konstytucji RP realizowane jest przez całokształt zasad prowadzących do rzetelnego i merytorycznie prawidłowego rozpoznania sprawy. Rozpatrzenie sprawy można uznać za sprawiedliwe, jeśli każda ze stron miała możliwość przedstawienia sądowi swych racji, skorzystania z prawa do obrony oraz zweryfikowania niekorzystnego dla niej rozstrzygnięcia przed sądem drugiej instancji. Mniej istotne jest to, czy postępowanie toczy się w pierwszej czy w drugiej instancji. Kluczowe jest, aby strona dysponowała możliwością realizacji swoich interesów w postępowaniu spełniającym standard rzetelnego procesu. Jeżeli zatem sąd odwoławczy został wyposażony w kompetencje dowodowe i jest uprawniony do orzekania reformatoryjnego, to postępowanie odwoławcze powinno zostać ukształtowane na tych samych zasadach prezentacji materiału, co postępowanie pierwszoinstancyjne. Realizacja tego warunku wymaga wyposażenia sądu drugiej instancji w narzędzia umożliwiające dokonanie własnych ustaleń, zarówno zbieżnych, jak i rozbieżnych z ustaleniami sądu pierwszej instancji. Nie jest zatem tak, że uzupełnienie materiału dowodowego w postępowaniu odwoławczym, czy też wydanie przez sąd odwoławczy wyroku reformatoryjnego, przesądza o konieczności zapewnienia stronie dalszej instancji.

Przenosząc powyższe rozważania na grunt postępowania w przedmiocie wydania wyroku łącznego, należy w pierwszej kolejności stwierdzić, że sprawa o wydanie wyroku łącznego jest sprawą w rozumieniu art. 45 ust. 1 Konstytucji RP, ${ }^{34}$

${ }_{33}$ M. Wiśniewski, Reformatoryjny model postępowania odwoławczego a zasada dwuinstancyjności postępowania, „Studenckie Zeszyty Naukowe” 2017, nr 32, s. 111.

${ }^{34}$ Por. wyrok TK z dnia 4 lipca 2018 r., K 16/16, OTK-A 2018, nr 52; wyrok TK z dnia 11 czerwca 2019 r., P 20/17, OTK-A 2019, poz. 29; wyrok TK z dnia 7 września 2004 r., P 4/04, OTK-A 2004, nr 8, poz. 81; wyrok TK z dnia 22 września 2015 r., P 37/14, OTK-A 2015, nr 8, poz. 121; wyrok TK z dnia 17 lipca 2013 r., SK 9/10, OTK-A 2013, nr 6, poz. 79; uchwała SN w składzie 7 sędziów z dnia 28 marca 2012 r., I KZP 26/11, OSNKW 2012, nr 4, poz. 36. 
która wymaga merytorycznego rozstrzygnięcia o prawach i wolnościach jednostki, w warunkach niezawisłości. ${ }^{35}$ Oznacza to, że w tego rodzaju sprawie aktualizuje się wynikający z art. 176 ust. 1 Konstytucji RP obowiązek zapewnienia stronom dostępu do środka zaskarżenia i możliwości rozpoznania sprawy w drugiej instancji, od której to zasady ustrojodawca nie dopuszcza żadnych wyjątków. ${ }^{36}$ Trzeba przy tym dostrzec, że specyfika postępowania w tej sprawie dostarcza podstaw do uznania możliwości w pełni merytorycznego orzekania przez sąd odwoławczy w tym postępowaniu. Przemawia za tym niewątpliwie fakt, że postępowanie to ma w zasadzie ograniczony zakres i w praktyce sprowadza się najczęściej do zapoznania się z dokumentami, co oznacza, że postępowanie dowodowe przedstawia się tak samo lub niemal tak samo przed sądem zarówno pierwszej, jak i drugiej instancji. W aspekcie zasady bezpośredniości, odmiennie niż w przypadku postępowania zwyczajnego, w postępowaniu w przedmiocie wydania wyroku łącznego między etapem pierwszoinstancyjnym a odwoławczym nie ma dostrzegalnej różnicy.

\section{4.}

Zdaje się również, że Sąd Najwyższy zasadniczo trafnie zidentyfikował sytuacje procesowe, w jakich sąd odwoławczy uprawniony jest do wymierzenia wyrokiem łącznym kary łącznej po raz pierwszy lub w wymiarze innym, niż uczynił to sąd pierwszoinstancyjny. Przede wszystkim nie budzi wątpliwości sytuacja, w której sąd odwoławczy rozpoznaje zażalenie na postanowienie, w którym sąd a quo stwierdził brak podstaw do wydania wyroku łącznego z przyczyn formalnych z powodu negatywnych przesłanek procesowych. Słusznie zauważa Sąd Najwyższy, że w takim układzie procesowym sąd a quo nie dokonuje oceny merytorycznej roszczenia procesowego o wydanie wyroku łącznego, lecz na etapie ją poprzedzającym - formalnym - uznaje, że z przyczyn pozamerytorycznych postępowanie podlega umorzeniu. Dlatego aprobatywnie należy wypowiedzieć się o poglądzie Sądu Najwyższego, że takie orzeczenie nie jest orzeczeniem co do istoty sprawy - w przedmiocie kary łącznej. W takim stanie procesowym na przeszkodzie merytorycznego orzeczenia przez sąd odwoławczy stoją nie tyle tylko względy trybu zażaleniowego (orzekanie $\mathrm{w}$ formie postanowienia i forum orzeczenia $\mathrm{w}$ postaci posiedzenia), lecz przede wszystkim właśnie implikacje zasady dwuinstancyjności. Niezasadne zaniechanie zbadania (w ogóle) materialnej podstawy wydania wyroku łącznego spowodowałoby skupienie całego ciężaru orzeczenia (faktycznego i prawnego) tylko na sądzie ad quem, stąd niemożliwe stałoby się zapewnienie prawa do dwukrotnej oceny stanu faktycznego i stanu prawnego sprawy.

${ }^{35}$ P. Grzegorczyk, K. Weitz, op.cit., s. 1105-1111.

${ }^{36}$ Wyrok TK z dnia 22 października 2015 r., SK 28/14, OTK-A 2015, nr 9, poz. 149. 
Z wyżej omówionym układem procesowym blisko powiązany jest ten, w którym sąd pierwszej instancji odmawia wydania wyroku łącznego z powodu braku spełnienia przesłanek materialnoprawnych, niezbędnych do orzeczenia kary łącznej. Należy zgodzić się z Sądem Najwyższym, że i w tym przypadku względy procedowania w trybie zażaleniowym wykluczają wydanie wyroku łącznego przez sąd odwoławczy. Należy jednak zastrzec, że w takiej sytuacji procesowej ograniczenia nie stanowi już zasada dwuinstancyjności, gdyż zakwestionowanie poglądu prawnego sądu pierwszej instancji co do podstawy prawnej rozpoznawanej kwestii (niedostateczne rozważenie przez sąd pierwszej instancji przepisów prawa materialnego) nie może oznaczać, że sąd ten nie rozpoznał przedmiotu sprawy. $Z$ tego też względu trafnie Sąd Najwyższy dostrzega, że możliwe jest orzeczenie przez sąd odwoławczy w sprawie o wydanie wyroku łącznego kary łącznej po raz pierwszy, gdy w zaskarżonym apelacją wyroku łącznym sąd pierwszej instancji wymierzył karę łączną na podstawie określonych wyroków jednostkowych, a w pozostałym zakresie umorzył postępowanie na zasadzie art. 572 k.p.k. Rolą sądu ad quem jest bowiem ponowna ocena stanu faktycznego i stanu prawnego sprawy, a jeśli po jej przeprowadzeniu sąd ten stwierdzi, że postępowanie przeprowadzone przed sądem $a$ quo było dotknięte wadami co do rodzaju dowodów przeprowadzonych przez ten sąd lub ich oceny oraz gdy stwierdzi, że doszło do nieprawidłowego zastosowania prawa materialnego ( $\mathrm{w}$ tym również wymagającego uzupełnienia ustaleń faktycznych), to ma obowiązek we własnym zakresie ustalenia te uzupełnić, a dowody ocenić ponownie.

Z tych samych względów należy zgodzić się ze stwierdzeniem Sądu Najwyższego, że dopuszczalne jest orzeczenie przez sąd odwoławczy wyroku łącznego na innej podstawie przedmiotowej, niż uczynił to sąd pierwszej instancji, tj. po uwzględnieniu błędnie niepołączonego przez sąd a quo podlegającego łączeniu wyroku jednostkowego czy też w sytuacji odwrotnej - po wyeliminowaniu wadliwie połączonego wyroku, który się do tego nie nadawał. Jednakże przy apelacji wniesionej na korzyść skazanego sąd odwoławczy związany będzie zakazem reformationis in peius $\mathrm{w}$ zakresie zasad wymiaru kary łącznej i poszanowania przyjętego przez sąd pierwszej instancji zakresu zasady asperacji. ${ }^{37}$

Na osobne odniesienie się zasługuje mieszcząca się w tezie drugiej glosowanej uchwały sytuacja, gdy zdatna do połączenia kara jednostkowa nie była w ogóle przedmiotem rozważań sądu $a$ quo, co mogło nastąpić na skutek uprawomocnienia się wyroku na etapie postępowania odwoławczego lub braku wiedzy sądu a quo

37 Por. M. Fingas, S. Steinborn, Glosa do postanowienia SN z dnia 5 czerwca 2012 r. (IV KK 22/12), „Przegląd Sądowy” 2013, nr 10, s. 128-138. 
o jej istnieniu. Podobnie należałoby ocenić sytuację, gdy podstawą orzeczenia kary łącznej miałyby być wyłącznie skazania jednostkowe niebędące podstawą orzeczenia kary łącznej przez sąd a quo. Prima vista wydaje się, że przekonujące są powołane przez Sąd Najwyższy powody, które uzasadniają objęcie wyrokiem łącznym sądu odwoławczego także takich kar jednostkowych. W postępowaniu o wydanie wyroku łącznego nie obowiązuje zasada skargowości, a sąd nie jest związany treścią wniosku skazanego, stąd wskazuje się, że obowiązkiem sądu - wynikającym zarówno z procesowej normy art. 570 k.p.k., jak i z normy materialnoprawnej z art. 85 k.k. - jest przeprowadzenie postępowania w zakresie wszystkich skazań danej osoby będącej podmiotem tego postępowania, celem ustalenia, czy popełnione przez nią przestępstwa pozostają $\mathrm{w}$ realnym zbiegu i przez to kary za nie orzeczone podlegają łączeniu. ${ }^{38} \mathrm{~W}$ sprawie o wydanie wyroku łącznego należy zatem brać pod uwagę wszystkie wyroki, jakimi dotychczas skazano osobę, w stosunku do której złożono wniosek i tym samym wyjaśnić wszystkie okoliczności pozwalające na dokładne ustalenie, czy zachodzą warunki do wydania wyroku łącznego. ${ }^{39}$

Pewne wątpliwości co do drugiej tezy komentowanej uchwały Sądu Najwyższego wywołuje jednak efekt analizy dokonanej z perspektywy specyfiki postępowania o wydanie wyroku łącznego i potencjalnych skutków orzeczenia sądu ad quem, wydanego z uwzględnieniem „nowego” skazania. Nie powinna wzbudzać kontrowersji teza, że w efekcie uwzględnienia w wyroku łącznym „nowego" skazania może nierzadko dojść do znacznego pogorszenia sytuacji skazanego na skutek istotnej modyfikacji kary, a mianowicie do wdrożenia jakościowo różnej sankcji poprzez orzeczenie kary łącznej bezwzględnego pozbawienia wolności w miejsce kary ograniczenia wolności (art. $87 \S 1$ k.k.) lub kary pozbawienia wolności z warunkowym zawieszeniem jej wykonania (art. 89 k.k.). W tym kontekście należy wyraźnie zaakcentować, że kara pozbawienia wolności - ze względu na znacznie głębszą ingerencję w sferę wolności osobistej - została uznana przez Trybunał Konstytucyjny za rodzajowo inną karę niż warunkowo zawieszona kara pozbawienia wolności. ${ }^{40}$ Pojawienie się „nowego” skazania na etapie postępowania odwoławczego w sprawie o wydanie wyroku łącznego może ponadto, w skrajnych przypadkach, doprowadzić do wymierzenia kary łącznej w postaci dożywotniego pozbawienia wolności (art. 88 in fine k.k.).

Mając na uwadze wyżej zarysowane, daleko idące skutki proponowanego przez Sąd Najwyższy rozwiązania, należałoby zastanowić się, czy dopuszczenie do wydania przez sąd ad quem wyroku łącznego w oparciu o nieznany sądowi a quo skazujący wyrok jednostkowy, tak z perspektywy specyfiki tego postępowania, jak i charakteru i wagi potencjalnych następstw tego rozstrzygnięcia, jawi

38 S. Steinborn, [w:] Kodeks postępowania karnego..., s. 487.

39 Wyrok SA w Łodzi z dnia 8 lipca 2009 r., II AKz 393/09, OSAŁ 2011, nr 1, poz. 10.

${ }^{40}$ Wyrok TK z dnia 22 września 2015 r., P 37/14, OTK-A 2015, nr 8, poz. 121. 
się jako prawidłowe i pożądane. Wydaje się, że właśnie z uwagi na szczególną specyfikę postępowania w sprawie o wydanie wyroku łącznego, odnoszącą się do kształtowania na nowo wymiaru kary, a więc kwestii związanej z wymierzaniem dolegliwości karnej, a tym samym godzącej w najdonioślejsze wartości - włączając $\mathrm{w}$ to wolność osobistą, zagrożony jest standard wyznaczony przez zasadę dwuinstancyjności postępowania. Należy zauważyć, że rozważania poświęcane zasadzie dwuinstancyjności postępowania zazwyczaj odnoszone są do postępowań głównych, które charakteryzuje pewna dwuwymiarowość rozstrzygnięcia, wyrażająca się w konieczności opowiedzenia się „,za lub przeciw” (np. przypisanie winy albo uniewinnienie, uwzględnienie powództwa albo jego oddalenie). Specyfika postępowania w sprawie o wydanie wyroku łącznego nie sprowadza się zaś do konieczności dokonania przez sąd dwubiegunowego wyboru, a polega na nowym ukształtowaniu wymiaru kary - określeniu kształtu kary łącznej, której zakres zależy od każdej z kar jednostkowych, co następuje zgodnie z uznaniem sędziowskim, w ramach którego nierzadko należy dokonać fakultatywnych wyborów. Wymierzenie kary łącznej polega na wymierzeniu jednej, nowej kary w miejsce prawomocnych kar jednostkowych, z zastosowaniem odrębnych dyrektyw i zasad jej wymiaru, nie będąc w żadnym wypadku operacją czysto matematyczną. Określenie kary łącznej, mimo że jest niezależne od rozstrzygnięcia o winie, stanowi wynik dokonanej przez sąd ogólnej oceny całokształtu działalności przestępczej sprawcy i podjęcia decyzji co do rodzaju i wymiaru kary w ustawowo przewidzianym zakresie. $\mathrm{W}$ zestawieniu z wyrokami jednostkowymi kara wymierzona w wyroku łącznym ma zatem nie tylko zmieniony wymiar $\mathrm{w}$ aspekcie ilościowym, le także - jak już wskazano - może zostać fakultatywnie przekształcona jakościowo. $Z$ tej perspektywy kara łączna, bazująca na innych karach jednostkowych, będzie zawsze karą inną, „nową", wstępującą w miejsce poprzednich.

W przypadku uwzględnienia kolejnej kary jednostkowej zmianie ulegają ramy przedmiotowe postępowania, a w konsekwencji również wymiar kary łącznej, zależący przecież od każdej z osobna z podlegających łączeniu kar. W postępowaniu o takiej specyfice nieuwzględnienie nieistniejącego wyroku jednostkowego nie stanowi więc tylko pominięcia w zakresie materiału dowodowego. W takiej sprawie ujawnienie „nowego” skazania nie ma charakteru technicznego, gdyż zawsze musi przekładać się na ramy przedmiotowe postępowania i na treść rozstrzygnięcia. Trudno zatem w omawianym układzie mówić jedynie o uzupełnieniu podstawy faktycznej przez sąd ad quem czy o orzeczeniu odmiennym (zmierzającym w przeciwnym kierunku) od sądu a quo, skoro oba sądy procedowałyby w zgoła odmiennych realiach, zobowiązujących do wydania różnokształtnych rozstrzygnięć. Tym samym rozpatrywaną sytuację należy uznać za istotowo odmienną od wypadku zmiany przez sąd odwoławczy wymiaru kary w postępowaniu zwyczajnym czy też zmiany wymiaru kary łącznej (przy zachowaniu tożsamej podstawy przedmiotowej). W opisywanym przypadku trudno dopatrywać się kontroli stanowiska 
zajętego przez sąd pierwszej instancji oraz dwukrotnej oceny stanu faktycznego i prawnego sprawy, skoro uwzględnienie nowych kar jednostkowych na etapie odwoławczym istotnie modyfikuje (poszerza) ramy przedmiotowe postępowania w stosunku do toczącego się przed sądem pierwszej instancji, tworząc tym samym nowy stan faktyczny i prawny, którego sąd a quo nie badał, a który oferuje inny wachlarz rozstrzygnięć. Wydaje się, że na skutek tak istotnych przekształceń przedmiotowych, jakie są w praktyce możliwe, tożsamość sprawy zostanie zachowana w sensie formalnym, ale już nie w sensie materialnym, gdyż nie występuje continuum względem podstawy przedmiotowej orzekania przyjętej przez sąd a quo.

W kontekście powyższego warto również przypomnieć, że postępowanie w sprawie o wydanie wyroku łącznego mieści się w konstytucyjnych ramach pojęcia ,sprawy”, wyznaczonych przez art. 45 ust. 1 Konstytucji RP. ${ }^{41}$ Tym samym od wyroku łącznego, jako orzeczenia niebędącego rozstrzygnięciem w kwestii incydentalnej, musi przysługiwać środek zaskarżenia o charakterze dewolutywnym. Jak wielokrotnie stwierdził Trybunał Konstytucyjny, orzekanie „w sprawie” wymaga wyższego poziomu gwarancji (w tym instancyjności połączonej z dewolutywnością), wobec czego w tym zakresie Konstytucja RP wymaga dwuinstancyjnego postępowania. ${ }^{42}$ Zdaniem Trybunału Konstytucyjnego typową formą kontroli orzeczeń sądowych jest ich ponowna ocena, dokonana przez sąd wyższej instancji. Jedynie wyjątkowo kontrola może nastąpić w tzw. instancji poziomej. ${ }^{43}$ Oczywiście ustawodawca ma pewien zakres swobody regulacyjnej podczas normowania postępowania przed sądem drugiej instancji, jednakże w sytuacjach objętych zakresem gwarancji konstytucyjnych ustawa nie może całkowicie zamykać dostępu do drugiej instancji ani nie może ustanawiać nieuzasadnionych ograniczeń, które nie odpowiadałyby wymogom określonym w art. 31 ust. 3 Konstytucji. ${ }^{44}$ Tak zaś należy postrzegać sytuację, którą zaaprobował Sąd Najwyższy w glosowanej uchwale. ${ }^{45}$

41 Por. rozważania zawarte w pkt 3 oraz orzecznictwo Trybunału Konstytucyjnego przywołane w przypisie 33 .

42 Por. wyrok TK z dnia 2 czerwca 2010 r., SK 38/09, OTK-A 2010, nr 5, poz. 46; wyrok TK z dnia 18 lipca 2011 r., SK 10/10, OTK-A 2011, nr 6, poz. 58; wyrok TK z dnia 12 kwietnia 2012 r., SK 21/11, OTK ZU-A 2012, nr 4, poz. 38; wyrok TK z dnia 22 października 2013 r., SK 14/13, OTK-A 2013, nr 7, poz. 100; wyrok TK z dnia 16 stycznia 2019 r., P 19/17, OTK-A 2019, poz. 9. Por. obszerną analizę tego problemu w: M. Kolendowska-Matejczuk, Zaskarżalność rozstrzygnięć incydentalnych uregulowanych $w$ Kodeksie postepowania karnego $w$ świetle standardów konstytucyjnych. Rozważania systemowe, Warszawa 2018, s. 252-258.

43 Wyrok TK z dnia 22 października 2013 r., SK 14/13, OTK-A 2013, nr 7, poz. 100 oraz powołane tam orzecznictwo.

44 Por. wyrok TK z dnia 12 września 2006 r., SK 21/05, OTK-A ZU 2006, nr 8, poz. 103.

$45 \mathrm{Z}$ tych względów należy zdecydowanie opowiedzieć się przeciwko dopuszczalności implementacji do procedury karnej środka zaskarżenia o charakterze niedewolutywnym, przysługującego od wyroku łącznego wydanego przez sąd odwoławczy, jako środka prawnego służącego rozwiązaniu analizowanego problemu. Byłoby to przy tym nie do pogodzenia z systemem kontroli odwoławczej 
Dopuszczalność postępowania zaproponowanego przez Sąd Najwyższy zdaje się też kolidować z instytucją skargi odwoławczej, nawet w warunkach specyficznego podejścia do zasady skargowości w postępowaniu o wydanie wyroku łącznego. $Z$ jednej strony trudno zapomnieć, że postępowanie odwoławcze ma jasno oznaczony cel, wytyczony przez środek odwoławczy wyznaczający dla stron ramy, w których sprawą będzie się zajmował sąd odwoławczy. Dlatego proponowane przez Sąd Najwyższy rozwiązanie każdorazowo musi prowadzić do wywołania u stron zaskoczenia, jakiego nie powinny zaznawać ze względu na istotę postępowania odwoławczego. Wydaje się jednak, że w kategorii wyjątku należy postrzegać jedynie sytuację, w której to strona powołuje nieznany wcześniej wyrok skazujący w środku odwoławczym, domagając się jego uwzględnienia i zajmując stanowisko odnoszące się do rozstrzygnięcia mającego ten wyrok za podstawę. $Z$ drugiej strony uwzględnienie w postępowaniu odwoławczym nowego skazania, nieznanego sądowi a quo, czyni możliwym postawienie skazanego, w następstwie zmiany przedmiotu postępowania (w wyżej rozumiany sposób) na etapie postępowania odwoławczego, w o wiele mniej korzystnej sytuacji, nawet w przypadku wniesienia apelacji na jego korzyść. Dopuszczalne staje się zatem uchybienie tym wartościom, jakie legły u podstaw wprowadzenia instytucji zakazu reformationis in peius.

Z powyższymi uwagami ściśle wiąże się kolejna. Jak już zauważono, w postępowaniu w przedmiocie wyroku łącznego ograniczono zasadę skargowości. Nie oznacza to jednak jeszcze, że ograniczone zostaje prawo do wysłuchania, będące jedną z podstawowych gwarancji prawa do obrony, należące zarazem do istoty prawa do sądu jako jeden z elementów zasady sprawiedliwości proceduralnej. ${ }^{46}$ W konsekwencji strony muszą mieć zapewnioną możliwość zaprezentowania swoich racji co do kwestii ustalenia podlegających łączeniu kar i okoliczności mających wpływ na wymiar kary łącznej, co powinno być respektowane na każdym etapie rozpoznawania sprawy - tak przed sądem pierwszej instancji, jak i przed sądem odwoławczym. Prezentując zaś swoje stanowisko, strony bezsprzecznie pozostają w określonych ramach przedmiotowych rozpoznawanej sprawy, w tym przypadku wyznaczonych ustalonymi w postępowaniu pierwszoinstancyjnym podlegającymi łączeniu karami jednostkowymi. Tymczasem kiedy przed sądem ad quem dochodzi do poszerzenia podstawy przedmiotowej orzekania o karze łącznej, strony (a zwłaszcza skazany) stawiane są w nowej rzeczywistości, do której muszą dostosować swoje stanowisko. Tym samym strony pozbawione są możliwości zaprezentowania stanowiska co do kształtu kary łącznej przed sądami dwóch instancji

\footnotetext{
w procesie karnym. Oznaczałoby to bowiem wprowadzenie kontroli odwoławczej wyroku wydanego w postępowaniu odwoławczym w układzie instancyjnym, choć takiego modelu postępowania odwoławczego procedura karna nie przewiduje. Trudno zaś uznać, aby podjęty w niniejszym opracowaniu problem wymagał tak poważnego przemodelowania czy wręcz porzucenia obowiązującego standardu.

${ }^{46}$ Wyrok TK z dnia 27 października 2015 r., K 5/14, OTK-A 2015, nr 9, poz. 150.
} 
w tym sensie, że ich stanowisko zaprezentowane przed sądem a quo może być poddane również sądowi ad quem. Kwestia ta nabiera szczególnego znaczenia, kiedy dostrzeże się, że zaaprobowany przez Sąd Najwyższy mechanizm może w praktyce spowodować wyodrębnienie się dwóch grup skazanych - tych, w sprawach których zakres przedmiotowy orzekania o karze łącznej był tożsamy przed sądami obu instancji (mogących zainicjować kontrolę wymiaru kary łącznej przed sądem odwoławczym i być wysłuchanymi przed sądami obu instancji) oraz tych, w sprawach których zakres przedmiotowy orzekania o karze łącznej uległ rozszerzeniu przed sądem odwoławczym (nie mogli skorzystać ze środka odwoławczego, wypowiadając się co do wszystkich kwestii podlegających rozstrzygnięciu jedynie przed sądem odwoławczym). Nie trzeba chyba nikogo przekonywać, że pierwsza z grup - przynajmniej potencjalnie - znajduje się w lepszej sytuacji procesowej. Dystynkcja ta zdaje się więc pozostawać w sprzeczności z zasadą równości wobec prawa. Jednocześnie trzeba nadmienić, że czymś innym jest uwzględnienie przez sąd ad quem kary jednostkowej, której sąd a quo w ogóle nie badał (gdyż nie posiadał wiedzy o jej istnieniu), od uwzględnienia kary, którą sąd a quo dostrzegł, a której połączenia niezasadnie odmówił. W drugim przypadku kara jednostkowa pozostawała bowiem w ramach przedmiotowych postępowania, a sąd $a$ quo i strony mogły wypowiedzieć się co do kwestii jej połączenia i wymiaru kary łącznej po jej uwzględnieniu.

Z powyższych względów należy wyraźnie zaakcentować, że zasada dwuinstancyjności relatywizowana jest do „procesu decyzyjnego", a sąd a quo - procedując co do wyroku łącznego - nie może mieć żadnej możliwości uwzględnienia nieistniejącego wówczas prawomocnego skazania, stąd nie stanowi ono przedmiotu jego oceny, bez wątpienia zaś uwzględnienie takiego skazania zawiodłoby go do innego rozstrzygnięcia. Zgoda na możliwość uwzględniania w postępowaniu odwoławczym nowego „skazania” może zatem zarazem oznaczać zgodę na arbitralność w wymiarze kary przez sąd ad quem, gdyż skazany nie będzie już miał możliwości samodzielnego doprowadzenia do jego kontroli. Warto zauważyć, że w takiej sytuacji - odmiennie niż w przypadku sięgnięcia przez sąd pierwszej instancji po niewskazany we wniosku wyrok jednostkowy - skazany pozbawiony jest możliwości kwestionowania współmierności wymierzonej mu kary (art. 523 § 1 zd. 2 k.p.k.). W przypadku gdy nie będzie możliwe realne sformułowanie zarzutu kasacyjnego innego niż zmierzający do kwestionowania słuszności wymiaru kary, skazany nie będzie mógł poddać ponownej ocenie stanu sprawy.

Szczególnego argumentu przeciwko poglądowi Sądu Najwyższego dostarcza także fakt, że w konsekwencji uwzględnienia przez sąd ad quem „nowego” skazania może dojść do fakultatywnego wdrożenia wobec skazanego kary izolacyjnej jako jakościowo odmiennej sankcji karnej, a więc kary o wiele bardziej ingerującej w jego konstytucyjne wolności i prawa. Należy tu wskazać na dwie sytuacje: 1) gdy „nowa”, uwzględniona przez sąd ad quem, kara będzie karą bezwzględnego 
pozbawienia wolności, a sąd a quo wymierzył karę łączną pozbawienia wolności z warunkowym zawieszeniem (art. 89 k.k.); 2) gdy orzeczona w pierwszej instancji kara łączna była karą ograniczenia wolności (art. 87 § 1 k.k.). Trzeba też zwrócić uwagę na preferencje ustrojodawcy wyartykułowane przez Trybunał Konstytucyjny w postanowieniu sygnalizacyjnym z dnia 9 listopada 2009 r. ${ }^{47} \mathrm{~W}$ ocenie Trybunału wzorce art. 42 ust. 2 i art. 176 ust. 1 Konstytucji RP są konsekwencją ogólniejszej wartości konstytucyjnej - szczególnej ochrony wolności człowieka, która to wartość wymaga formowania zaostrzonych wymagań co do gwarancji proceduralnych towarzyszących każdemu pozbawieniu wolności. Taką gwarancję stanowi konieczność poddania każdej decyzji o pozbawieniu wolności stosownej, sądowej kontroli, a więc środek odwoławczy. Tym samym Trybunał Konstytucyjny wyraził przekonanie, że zasadę dwuinstancyjności należy postrzegać w kategoriach gwarancji proceduralnych przestrzegania innych zasad konstytucyjnych. Wartością chronioną w szczególny sposób w sprawach karnych jest wolność osobista, stąd gdy dochodzi do jej pozbawienia na mocy orzeczenia sądu, zawsze takie orzeczenie powinno podlegać kontroli instancyjnej, nie wykluczając jednak tzw. instancji poziomej w przypadkach ubocznych ${ }^{48}$ Klaruje się zatem wniosek, że dopuszczenie do możliwości uwzględnienia przez sąd ad quem nieznanego sądowi a quo wyroku jednostkowego może doprowadzić do sytuacji, w której skazany, wobec którego wymierzono wyrokiem sądu ad quem karę rodzajowo inną w postaci kary izolacyjnej, pozbawiony zostanie możliwości sądowej kontroli tego orzeczenia, nawet w sytuacji gdy sąd ad quem wymierzy karę łączną dożywotniego pozbawienia wolności.

Jednocześnie wypada zauważyć, że ograniczoną siłę przekonywania mają powołane przez Sąd Najwyższy względy ekonomii postępowania, jakie mają przemawiać za możliwością uwzględnienia przez sąd ad quem podlegającej łączeniu kary, co do której sąd a quo się nie wypowiedział. Trybunał Konstytucyjny już kilkakrotnie miał okazję wyrazić stanowisko, że szybkość rozpoznania sprawy nie jest wartością, na rzecz której można poświęcić ochronę praw podmiotowych. Uproszczenie i przyspieszenie mogą niewątpliwie dotyczyć kwestii formalnych, natomiast w żadnym wypadku nie mogą odnosić się do uprawnień stron wiążących się z obroną ich praw i interesów. ${ }^{49}$ Trybunał sugerował przy tym, że sprawność procedowania można osiągnąć za pomocą innych mechanizmów niż wyłączanie stronom drogi odwoławczej w postępowaniu sądowym. ${ }^{50}$

${ }^{47}$ S 7/09, OTK-A 2009, nr 10, poz. 154.

48 D. Świecki, op. cit., s. 224-225.

49 Wyrok TK z dnia 12 marca 2002 r., P 9/01, OTK ZU 2002, nr 2A, poz. 14; wyrok TK z dnia 13 stycznia 2004 r., SK 10/03, OTK ZU 2004, nr 1A, poz. 2; wyrok TK z dnia 2 października 2006 r., SK 34/06, OTK-A 2006, nr 9, poz. 118.

${ }^{50}$ Wyrok TK z dnia 12 czerwca 2002 r., P 13/01, OTK-A 2002, nr 4, poz. 42. 
Wydaje się zatem, że w przypadku ujawnienia się na etapie postępowania odwoławczego kary jednostkowej nieuwzględnionej przez sąd pierwszej instancji, jako konieczne jawi się albo uchylenie wyroku łącznego i przekazanie sprawy do ponownego rozpoznania, albo zainicjowanie kolejnego postępowania w sprawie o wydanie wyroku łącznego - w celu zapewnienia skazanemu prawa do dwukrotnej kontroli sprawy oraz wykluczenia arbitralności sądu odwoławczego. Jak wyżej zasugerowano, możliwość uwzględnienia tego rodzaju novum w postępowaniu odwoławczym wydaje się jednak stać otworem, gdy to sam oskarżony ujawni nieznane dotąd skazanie w wywiedzionej apelacji i zażąda włączenia go do podstawy przedmiotowej orzekania sądu odwoławczego.

6.

W podsumowaniu trzeba stwierdzić, że przenosząc standard wyznaczony zasadą dwuinstancyjności postępowania sądowego na grunt sprawy o wydanie wyroku łącznego, należy uwzględnić szczególną specyfikę tego postępowania. Wydaje się, że sąd odwoławczy nie powinien orzekać merytorycznie w następstwie rozpoznania zażalenia na umorzenie postępowania. Inaczej jednak będzie, gdy sąd a quo wyda wyrok łączny, w którym częściowo wymierzy karę łączną, a częściowo postępowanie umorzy - wówczas dopuszczalne jest wydanie przez sąd ad quem wyroku łącznego jako efektu odmiennej oceny w zakresie możliwości połączenia skazań czy wymiaru kary łącznej. Szereg wątpliwości budzi jednak sytuacja, gdy na etapie postępowania odwoławczego pojawi się nieznana sądowi a quo podlegająca łączeniu kara jednostkowa. Wydaje się, że w takim układzie procesowym sąd ad quem co do zasady nie powinien procedować co do „nowego” skazania, gdyż skazanie to nie stanowiło przedmiotu postępowania przed sądem a quo, a słuszność kary łącznej, wymierzonej z jego uwzględnieniem przez sąd ad quem w wyroku łącznym, wymyka się kontroli instancyjnej. Tezę tę wzmacnia również fakt, że w następstwie uwzględnienia „nowego" skazania na etapie postępowania odwoławczego mogłoby dojść do fakultatywnego wymierzenia skazanemu kary izolacyjnej (w tym kary dożywotniego pozbawienia wolności). Wyjątkiem może być tylko sytuacja, gdy to strona w wywiedzionym środku odwoławczym ujawnia nieznane dotąd skazanie i domaga się jego uwzględnienia przez sąd odwoławczy.

De lege ferenda wydaje się, że w przypadku ujawnienia przez sąd odwoławczy, w sprawie o wydanie wyroku łącznego, wyroku jednostkowego nieuwzględnionego przy wydawaniu wyroku łącznego przez sąd pierwszej instancji, sąd odwoławczy powinien mieć możliwość uchylenia zaskarżonego wyroku łącznego i przekazania sprawy do rozpoznania sądowi pierwszej instancji w celu przeprowadzenia postępowania w zakresie wszystkich skazań. 


\section{BIBLIOGRAFIA}

\section{Literatura}

Blanke H.J., [w:] EUV/AEUV. Das Verfassungsrecht der Europäischen Union mit Europäischer Grundrechtecharta Kommentar, hrsg. v. Ch. Caliess, M. Ruffert, München 2011.

Błoński M., Zasada dwuinstancyjności a reformatoryjny wyrok sądu odwoławczego, [w:] Istota i zasady procesu karnego 25 lat później. Księga poświęcona pamięci Profesora Andrzeja Murzynowskiego, red. H. Gajewska-Kraczkowska, M. Rogacka-Rzewnicka, Warszawa 2019.

Fingas M., Orzekanie reformatoryjne w instancji odwoławczej w polskim procesie karnym, Warszawa 2016.

Fingas M., Steinborn S., Glosa do postanowienia SN z dnia 5 czerwca 2012 r. (IV KK 22/12), „Przegląd Sądowy” 2013, nr 10.

Gliszczyńska-Grabias A., Sękowska-Kozłowska K., Wieruszewski R., [w:] Międzynarodowy Pakt Praw Obywatelskich (osobistych) i Politycznych. Komentarz, red. R. Wieruszewski Warszawa 2012.

Grajewski J., Steinborn S., [w:] Kodeks postepowania karnego. Komentarz, red. L.K. Paprzycki, t. 2, Warszawa 2013.

Grzegorczyk P., Weitz K., [w:] Konstytucja RP. Komentarz, red. L. Bosek, M. Safjan, t. 1, Warszawa 2016.

Hermeliński W., Nita B., Orzekanie reformatoryjne w procesie karnym na podstawie nowych ustaleń faktycznych, „Państwo i Prawo” 2009, z. 4.

Hofmański P., Nowy model postepowania odwoławczego w postepowaniu karnym, [w:] Postepowanie odwoławcze w procesie karnym - u progu nowych wyzwań, red. S. Steinborn, Warszawa 2016.

Hofmański P., Wróbel A., Komentarz do Konwencji o ochronie praw człowieka i podstawowych wolności, t. 1, Warszawa 2010.

Hofmański P., Zabłocki S., Dowodzenie w postępowaniu apelacyjnym i kasacyjnym - kwestie modelowe, [w:] Funkcje procesu karnego. Księga jubileuszowa Profesora Janusza Tylmana, red. T. Grzegorczyk, Warszawa 2011.

Jasiński W., Redukcja postępowania przed sądem pierwszej instancji a konstytucyjny i konwencyjny standard prawa do odwołania się w sprawach karnych, [w:] Postępowanie odwoławcze w procesie karnym - u progu nowych wyzwań, red. S. Steinborn, Warszawa 2016.

Kaftal A., System środków odwoławczych w polskim procesie karnym (rozważania modelowe), Warszawa 1972.

Klejnowska M., Ograniczenia sądu odwoławczego orzekajacego w sprawie karnej po wniesieniu środka zaskarżenia, Rzeszów 2008.

Kolendowska-Matejczuk M., Zaskarżalność rozstrzygnięć incydentalnych uregulowanych w Kodeksie postępowania karnego w świetle standardów konstytucyjnych. Rozważania systemowe, Warszawa 2018.

Nowicki M.A., Wokół Konwencji Europejskiej. Komentarz do Europejskiej Konwencji Praw Człowieka, Warszawa 2017.

Steinborn S., [w:] Kodeks postępowania karnego. Komentarz, red. L.K. Paprzycki, t. 2, Warszawa 2013.

Steinborn S., Ograniczenie zaskarżalności wyroku wydanego w I instancji jako środek uproszczenia procesu karnego $w$ świetle prawa do dwuinstancyjnego postepowania (uwagi de lege lata i de lege ferenda), „Gdańskie Studia Prawnicze” 2005, nr 1.

Steinborn S., Postępowanie dowodowe w instancji apelacyjnej w świetle nowelizacji kodeksu postępowania karnego, „Prokuratura i Prawo” 2015, nr 1-2.

Świecki D., Konstytucyjna zasada dwuinstancyjności postepowania sądowego a możliwość reformatoryjnego orzekania w instancji odwoławczej w świetle wchodzacej w życie 1 lipca 2015 r. nowelizacji kodeksu postepowania karnego, [w:] Polski proces karny i materialne prawo karne 
w świetle nowelizacji z 2013 roku. Księga jubileuszowa dedykowana Profesorowi Januszowi Tylmanowi z okazji Jego 90. urodzin, red. T. Grzegorczyk, Warszawa 2014.

Wąsek-Wiaderek M., Wybrane aspekty postępowania odwoławczego w procesie karnym po 1 lipca 2015 r. w świetle standardów międzynarodowych, [w:] Postępowanie odwoławcze w procesie karnym - u progu nowych wyzwań, red. S. Steinborn, Warszawa 2016.

Wiliński P., Dwuinstancyjność postepowania karnego w świetle Konstytucji, [w:] Funkcje procesu karnego. Księga jubileuszowa Profesora Janusza Tylmana, red. T. Grzegorczyk, Warszawa 2011.

Wiliński P., Konstytucyjne gwarancje prawa karnego procesowego, [w:] System Prawa Karnego Procesowego, t. 1, cz. 1: Zagadnienia ogólne, red. P. Hofmański, Warszawa 2013.

Wiliński P., Konstytucyjne uwarunkowania postepowania odwoławczego w procesie karnym, [w:] Postępowanie odwolawcze $w$ procesie karnym - u progu nowych wyzwań, red. S. Steinborn, Warszawa 2016.

Wiśniewski M., Reformatoryjny model postępowania odwoławczego a zasada dwuinstancyjności postepowania, „Studenckie Zeszyty Naukowe” 2017, nr 32,

DOI: http://dx.doi.org/10.17951/szn.2017.20.32.103.

\section{Akty prawne}

Karta Praw Podstawowych Unii Europejskiej (Dz.Urz. UE C 303, 14.12.2007).

Konstytucja Rzeczypospolitej Polskiej z dnia 2 kwietnia 1997 r. (Dz.U. 1997, nr 78, poz. 483 ze zm.).

Konwencja o Ochronie Praw Człowieka i Podstawowych Wolności z dnia 4 listopada 1950 r. (Dz.U. 1993, nr 61, poz. 284 ze zm.).

Międzynarodowy Pakt Praw Obywatelskich i Politycznych z dnia 19 grudnia 1966 r. (Dz.U. 1977, nr 38, poz. 167).

Protokół nr 7 do Konwencji o Ochronie Praw Człowieka i Podstawowych Wolności z dnia 22 listopada 1984 r. (Dz.U. 2003, nr 42, poz. 364).

Ustawa z dnia 6 czerwca 1997 r. - Kodeks postępowania karnego (t.j. Dz.U. 2020, poz. 30 ze zm.).

\section{Orzecznictwo}

Decyzja Komitetu Praw Człowieka z dnia 28 marca 2006 r., Bandajewski v. Białoruś, skarga nr 1100/2002.

Decyzja Komitetu Praw Człowieka z dnia 24 lipca 2006 r., Larranaga v. Filipiny.

Postanowienie SN z dnia 8 grudnia 2010 r., II KK 288/10, BPK 2011, nr 1, poz. 1.

Postanowienie SN z dnia 27 stycznia 2015 r., IV KK 195/14, OSP 2016, nr 2, poz. 18.

Postanowienie SN z dnia 24 października 2017 r., V KK 265/17, LEX nr 2408341.

Postanowienie TK z dnia 9 listopada 2009 r., S 7/09, OTK-A 2009, nr 10, poz. 154.

Postanowienie TK z dnia 14 maja 2013 r., Ts 216/12, OTK-B 2013, nr 5, poz. 498.

Postanowienie TK z dnia 24 maja 2017 r., Ts 205/16, OTK-B 2017, poz. 149.

Uchwała SN w składzie 7 sędziów z dnia 23 marca 2011 r., I KZP 28/10, OSNKW 2011, nr 4, poz. 30.

Uchwała SN w składzie 7 sędziów z dnia 28 marca 2012 r., I KZP 26/11, OSNKW 2012, nr 4, poz. 36.

Uchwała SN w składzie 7 sędziów z dnia 28 czerwca 2018 r., I KZP 3/18, OSNKW 2018, nr 8, poz. 55.

Wyrok ETPC z dnia 17 stycznia 1970 r., Delcourt v. Belgia, skarga nr 2689/65.

Wyrok ETPC z dnia 26 października 2000 r., Kudła v. Polska, skarga nr 30210/96.

Wyrok ETPC z dnia 22 lutego 2011 r., Lalmahomed v. Holandia, skarga nr 26036/08.

Wyrok ETPC z dnia 30 października 2014 r., Shyvdka v. Ukraina, skarga nr 17888/12.

Wyrok ETPC z dnia 4 czerwca 2015 r., Ruslan Yakovenko v. Ukraina, skarga nr 5425/11.

Wyrok ETPC z dnia 25 lipca 2017 r., Rostovtsev v. Ukraina, skarga nr 2728/16.

Wyrok ETPC z dnia 9 listopada 2017 r., Firat v. Grecja, skarga nr 46005/11.

Wyrok ETPC z dnia 30 stycznia 2018 r., Brajović v. Czarnogóra, skarga nr 52529/12. 
Wyrok SA w Katowicach z dnia 10 stycznia 2008 r., II AKa 546/07, KZS 2008, nr 4, poz. 109.

Wyrok SA w Łodzi z dnia 8 lipca 2009 r., II AKz 393/09, OSAŁ 2011, nr 1, poz. 10.

Wyrok SA w Katowicach z dnia 4 kwietnia 2013 r., II AKa 53/13, LEX nr 1311956.

Wyrok SN z dnia 26 marca 2008 r., V KK 389/07, OSNKW 2008, nr 8, poz. 61.

Wyrok SN z dnia 18 listopada 2008 r., II KK 121/08, BPK 2009, nr 1, poz. 10.

Wyrok TK z dnia 12 marca 2002 r., P 9/01, OTK ZU 2002, nr 2A, poz. 14.

Wyrok TK z dnia 12 czerwca 2002 r., P 13/01, OTK-A 2002, nr 4, poz. 42.

Wyrok TK z dnia 11 marca 2003 r., SK 8/02, OTK-A 2003, nr 3, poz. 20.

Wyrok TK z dnia 13 stycznia 2004 r., SK 10/03, OTK ZU 2004, nr 1A, poz. 2.

Wyrok TK z dnia 17 maja 2004 r., SK 32/03, OTK-A 2004, nr 5, poz. 44.

Wyrok TK z dnia 7 września 2004 r., P 4/04, OTK-A 2004, nr 8, poz. 81.

Wyrok TK z dnia 12 września 2006 r., SK 21/05, OTK-A ZU 2006, nr 8, poz. 103.

Wyrok TK z dnia 2 października 2006 r., SK 34/06, OTK-A 2006, nr 9, poz. 118.

Wyrok TK z dnia 28 kwietnia 2009 r., P 22/07, OTK-A 2009, nr 4, poz. 55.

Wyrok TK z dnia 13 lipca 2009 r., SK 46/08, OTK-A 2009, nr 7, poz. 109.

Wyrok TK z dnia 12 stycznia 2010 r., SK 2/09, OTK-A 2010, nr 1, poz. 1.

Wyrok TK z dnia 2 czerwca 2010 r., SK 38/09, OTK-A 2010, nr 5, poz. 46.

Wyrok TK z dnia 18 lipca 2011 r., SK 10/10, OTK-A 2011, nr 6, poz. 58.

Wyrok TK z dnia 12 kwietnia 2012 r., SK 21/11, OTK ZU-A 2012, nr 4, poz. 38.

Wyrok TK z dnia 17 lipca 2013 r., SK 9/10, OTK-A 2013, nr 6, poz. 79.

Wyrok TK z dnia 22 października 2013 r., SK 14/13, OTK-A 2013, nr 7, poz. 100.

Wyrok TK z dnia 22 września 2015 r., P 37/14, OTK-A 2015, nr 8, poz. 121.

Wyrok TK z dnia 22 października 2015 r., SK 28/14, OTK-A 2015, nr 9, poz. 149.

Wyrok TK z dnia 27 października 2015 r., K 5/14, OTK-A 2015, nr 9, poz. 150.

Wyrok TK z dnia 4 lipca 2018 r., K 16/16, OTK-A 2018, nr 52.

Wyrok TK z dnia 16 stycznia 2019 r., P 19/17, OTK-A 2019, poz. 9.

Wyrok TK z dnia 11 czerwca 2019 r., P 20/17, OTK-A 2019, poz. 29.

Wyrok TSUE z dnia 17 lipca 2014 r. w sprawie C-169/16, Sánchez Morcillo i Abril García, ECLI:EU:C:2014:2099.

\section{ABSTRACT}

The commentary raises the problem of the admissibility of the issuing cumulative penalty in cumulative judgement by appeal court for the first time or issuing that penalty within the different scope of punishment, from the perspective of the power to alter decisions of a court of the first instance, the principle of two-instance court proceedings, access to court and the right of defence. By discussing the essence of the constitutional and convention provisions, the author attempts to answer the question what the scope of the appeal court's power is to alter cumulative judgement issued in the first instance, by concluding that neither Article 176 (1) of the Polish Constitution, nor Article 6 of the European Convention on Human Rights (ECHR) and Article 2 of Protocol no. 7 to the ECHR supplementing its content, as well as Article 14 (5) of the International Covenant on Civil and Political Rights in principle stand in the way of such an approach, which should be reflected in the process of interpretation of Article 437 (2) of the Code of Criminal Procedure. However, in the author's opinion, doubts arise, from the perspective discussed above, if the appellate court were to take into account, when imposing the cumulative penalty, a unit judgement unknown, for various reasons, to the court of first instance, to which a special part of the considerations and critical remarks is devoted.

Keywords: criminal procedure; appeal court; principle of two-instance court proceedings; access to court; right of defence; cumulative judgement 